\title{
191. Generator Potentials of Stretch Receptors in the Frog Sartorius Muscle
}

\author{
By Fumio Iтo \\ Department of Physiology, School of Dentistry, Aichi-Gakuin \\ University, Nagoya \\ (Comm. by Yas Kuno, M. J. A., Oct. 12, 1968)
}

It has been demonstrated that the difference in adaptation rates between two types of stretch receptor cells in the crayfish due to differences in the properties of their electrically excitable membrane components rather than to differences in the mechanisms of their generator potentials. ${ }^{1)}$ In many mechano-receptors, however, mechanical properties have been regarded as the important factor in the coupling between the receptor and the stimulus. ${ }^{2)}$

Two types of stretch receptors which lie side by side in the frog sartorius muscle exhibit a marked difference in adaptation ;3) muscle spindles are slowly adapting, leaf-like receptors adapt very rapidly. The latter have been assumed to correspond to the pressure-pain receptors in mammalian skeletal muscles, ${ }^{4)}$ because they respond in a similar manner during passive stretch or upon contraction of muscle. ${ }^{5)}$

A single afferent nerve fiber supplying a spindle or a leaf-like receptor was isolated in its intramuscular course in the frog sartorius muscle. Successful observations of 32 spindle and 18 leaf-like receptors were obtained from 56 muscles. The receptors were identified by their functional properties, ${ }^{5)}$ with microscopical observations or by measurement of the conduction velocities of their afferent impulses. ${ }^{6)}$ The preparation was placed in a Ringer's pool (RA1) in a perspex box, and the nerve was passed into another Ringer's pool (RB1) through a liquid paraffin pool $(1 \mathrm{~mm}$ length) situated in a $1 \mathrm{~mm}$ wide slit at the center of a partition between the two Ringer's pools. The boundary between the paraffin and the Ringer's solution in RA1 was maintained by the surface tension of the two solutions. Thus, the nerve could move sideways within the slit, without damage when the muscle was stretched by $2 \mathrm{~mm}$. The distance from the boundary of the slit to the site of the receptor was usually kept within $1 \mathrm{~mm}$. Responses of receptors were led from the two pools to a pair of calomel electrodes through Ringer-agar bridges and were displayed on a dual beam oscilloscope with a high input-impedance DC amplifier. In this recording condition, recorded potentials were due to current 
A

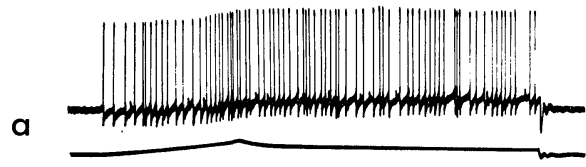

b

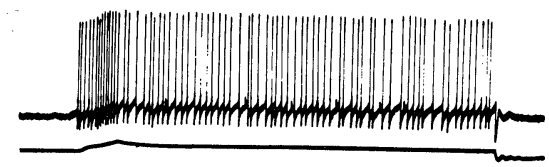

c

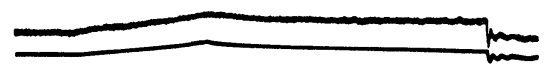

d

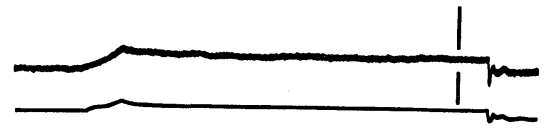

B
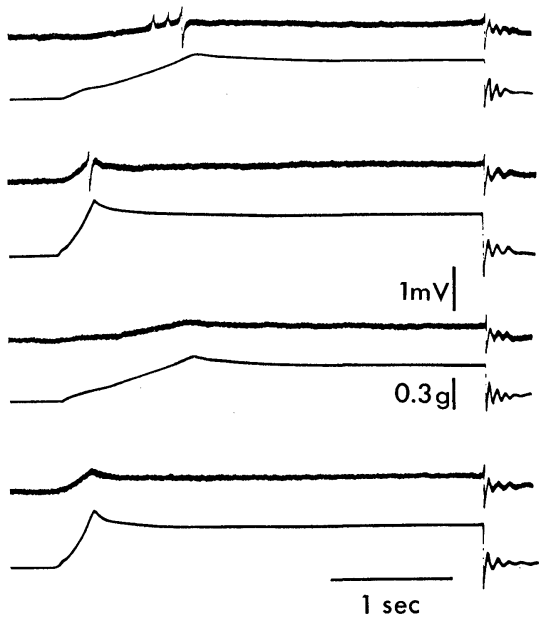

Fig. 1. A: Repetitive discharges superimposed upon generator potentials from a spindle receptor (upper traces) and muscle tensions (lower traces) during stretch of the muscle by $2 \mathrm{~mm}$ from $+0 \mathrm{~mm}$ at the velocities of $1 \mathrm{~mm} / \mathrm{sec}$ (a) and $6 \mathrm{~mm} / \mathrm{sec}(\mathrm{b})$. Abortive spikes can be noted among the propagated spikes. (c) and (d): Time courses of the generator potentials. The same spindle after it had been treated with tetrodotoxin $\left(10^{-6} \mathrm{~g} / \mathrm{ml}\right)$. Muscle stretched at 1 and $6 \mathrm{~mm} / \mathrm{sec}$ respectively. B: Abortive and propagated discharges superimposed upon generator potentials from a leaf-like receptor (upper traces) and muscle tensions (lower traces) during stretch of the muscle by $2 \mathrm{~mm}$ from $+4 \mathrm{~mm}$ length at the same velocities as did in A, a and b. (c) and (d): After treatment with tetrodotoxin $\left(10^{-6} \mathrm{~g} / \mathrm{ml}\right)$.

flow along the external longitudinal resistance (2-3 $\mathrm{M} \Omega$ ) of the axon at the paraffin pool. Negativity at the electrode in $\mathrm{RA1}$ relative to the electrode in RB1 was displayed as an upward deflection. The muscle was stretched by $2 \mathrm{~mm}$ from the in situ length $(+0 \mathrm{~mm})$ by means of a stretcher, which was driven by a sawtooth current producing a constant velocity during stretch. ${ }^{7}$ ) Tension changes of the muscle were transduced by an RCA 5734 tube at the fixed end.

Fig. $1 \mathrm{~A}, \mathrm{a}$ and $\mathrm{b}$ show responses of a spindle receptor (upper traces) during stretch of the muscle at 1 and $6 \mathrm{~mm} / \mathrm{sec}$ respectively. The muscle tension (lower traces) gradually increased and after a peak at completion of the stretch attained a new steady level approximately $0.1 \mathrm{~g}$ higher than the initial tension. During the dynamic phase of the tension increment, propagated and abortive spikes occurred frequently on a base line of slow depolarization. The latter appears to be a generator potential, because it was abolished, together 
with the other electric changes, when the axon was crushed at the point of entry into the capsule (see Katz) ${ }^{8)}$ Tetrodotoxin $\left(10^{-6} \mathrm{~g} / \mathrm{ml}\right.$ in the Ringer's solution) wiped out the spikes, and revealed the generator potential,1),9) as illustrated in Fig. 1A, c and d. The time course of the generator potential was similar to that of the tension changes in the muscle, and its amplitude attained approximately $205 \mu \mathrm{V}$ regardless of stretch velocity.

Leaf-like receptors did not respond to the same amount of muscle stretch as did the spindle receptors. When the muscle was stretched by $2 \mathrm{~mm}$ from $+4 \mathrm{~mm}$ initial length at velocities of 1 and $6 \mathrm{~mm} / \mathrm{sec}$, the muscle tension showed an apparent over-shoot, of up to $0.5 \mathrm{~g}$, and then attained a new steady level of $0.3 \mathrm{~g}$. A few abortive and propagated spikes occurred during the rising phase of the generator potential, as illustrated in Fig. 1B, a and b. Tetrodotoxin abolished the abortive and propagated spikes, but did not abolish the generator potential. The time course of the generator potential of the leaf-like receptor did not differ essentially from that of the spindle receptor. However, the amplitude of the generator potentials recorded from the leaf-like receptors was less-one fourth to one seventh-of that measured in the spindle receptors, when the muscle was stretched to develop the same tension. Several possibilities could account for these differences.

It is concluded that the difference in adaptation rates between the two types of stretch receptors in the frog sartorius muscle should be attributed to a difference in the properties of their electrically excitable membrane components.

Acknowledgments. I am indebted to Prof. M. Sato in the Department of Physiology, Kumamoto University Medical School, Kumamoto, Japan, for his helpful discussion and for his correction of English manuscript. A part of this work was supported by Public Health Service Research Grant NB 04671.

\section{References}

1) Nakajima, S.: Science, 146, 1168 (1964).

2) Lippold, O. C. J., Nicholls, J. G., and Redfearn, J. W. T.: J. Physiol., 153, 209 (1960); Loewenstein, W. R., and Mendelson, M.: J. Physiol., 177, 377 (1965); Loewenstein, W. R., and Skalak, R.: J. Physiol., 182, 346 (1966); Catton, W. T.: J. Physiol., 187, 23 (1966); Catton, W. T., and Petoe, N.: J. Physiol., 187, 35 (1966).

3) Kobayashi, Y., Oshima, K., and Tasaki, I.: J. Physiol., 117, 152 (1952); Ito, F., Toyama, K., and Ito, R.: Jap. J. Physiol., 14, 12 (1964).

4) Paintal, A. S.: J. Physiol., 152, 250 (1960).

5) Ito, F.: Jap. J. Physiol., 18, 590 (1968).

6) Matthews, P. B. C., and Westbury, D. R.: J. Physiol., 178, 178 (1965). 
7) Bach-y-Rita, P., and Ito, F.: J. Physiol., 186, 663 (1966).

8) Katz, B.: J. Physiol., 111, 248 (1950a); Katz, B.: J. Physiol., 111, 261 (1950b).

9) Kao, C. Y.: Pharmacol. Rev., 18, 997 (1966). 